\title{
Major repair and reconstruction of the historical housing development in Saint Petersburg
}

\author{
Galina Tokunova*, Irina Drozdova, Evgeny Shesterov \\ Saint Petersburg State University of Architecture and Civil Engineering, Saint Petersburg, Russia
}

\begin{abstract}
The article provides results of housing technical state examination in the historical development of Saint Petersburg, performed by experts of the Saint Petersburg State University of Architecture and Civil Engineering. The described methodology developed by the authors serves a basis to find the most efficient solution for issues arising in Saint Petersburg, and fully meets all social, scientific, technical and economic conditions of modern urban development. This is especially important when implementing the concepts of Smart City and Smart Home intended to become a basis for development of modern urban environment within the existing historical city. As for cultural heritage sites, it is possible to extend the useful life of a historical building by its timely reconstruction. Reconstruction shall be performed following a clear plan with account for the sequence of stages: from handing archive materials and a city plan to identify the historical appearance of a building to a possible need for reconstruction of not only a separate building but also a whole block. In case of a major repair of an apartment building, or reconstruction of historical cultural heritage sites, activities improving energy efficiency of buildings are required, which are associated with significant costs that sometimes exceed the federal or city budget.
\end{abstract}

\section{Introduction}

The entire global community is currently at the edge of urbanistic revolution rapidly bringing about the era of smart cities that promise to be ultra-hi-tech, ultra-comfortable, innovative, dynamic, and environmentally friendly.

The statistics shows that modern cities occupy only $2 \%$ of land, but $55 \%$ of the global population live in them. They are responsible for $60 \%$ of global energy consumption and generate $70 \%$ of greenhouse gas emissions [1-3]. The city has become the primary backbone of the modern civilization and, at the same time, the most vulnerable and problematic place of human habitation. Therefore, modern economists, city planners, and environmental experts pay attention to studying the development of modern cities so as to propose new modern forms of solving urbanistic issues.

The Smart City concept as one of the high priority trends in the field of urban population life support (including that in Russia) is now actively studied and implemented

\footnotetext{
* Corresponding author: tgf 1608@mail.ru
} 
in cities. The largest European cities, including Moscow and Saint Petersburg, are nowadays oriented towards the Smart City 2.0 strategy [2-5]. Among the trends in implementing smart technologies into the city infrastructure, smart management and smart economy can be mentioned. In practice, this suggests formation of a modern hi-tech city environment that has health-friendly accommodation built using the smart home model where energy consumption is reduced, thus saving energy resources [3-4]. In this city concept 2.0, the policy of small projects within the existing borders becomes of high priority [5-8].

With respect to the above-mentioned smart city trends, the key factor of the Russian state policy is an economic development model based on the maximum use of internal resources [9].

\section{Methods}

The study was conducted based on a systemic approach to the analysis of issues related to the condition and development of the residential sector in the historical center. The methods of historical-logical, statistical, comparative and structural-functional analysis were applied. Based on the analysis of a large amount of statistical materials describing the condition and development perspectives of the residential sector in Russia and in foreign countries, the authors revealed basic barriers when proceeding to implementation of the Smart City concept in Russian historical cities [10-13]. The authors developed a methodology for technical inspection of buildings in the historical center, which serves as a basis for an integrated approach to solving social, scientific, technical and economic tasks.

\section{Results and Discussion}

The global experience of economic development shows that the expensive development path requires significant resources to be included in the turnover. An alternative model is based on energy saving and energy efficiency. Saving energy resources is equal to their production. This path of development allows for more efficient solution of economic and environmental issues and satisfaction of rising social needs of the community.

As compared with other sectors of economy, the sector of buildings is characterized by the most significant potential in the area of energy saving [14-18]. Energy saving can be primarily obtained thanks to implementation of respective process solutions - from simple to complex ones. Even the simplest and, nevertheless, cost-effective projects in modernization of buildings provide up to $40 \%$ of energy saving $[19,20]$.

The structure of fuel and energy resources consumption in European countries shows that about $40 \%$ of those are consumed by buildings, therefore, this sector has a high potential in terms of energy saving program implementation [21, 22].

All primary stocks existing in Russia (including residential houses, industrial and public buildings) do not meet increasing requirements for energy efficiency. Their maintenance is unjustifiably expensive for state/municipal budgets and owners.

This is also confirmed by the analysis of the technical condition of the residential stock in the historical development of Saint Petersburg. The analysis was based on the results of technical inspection of historical buildings, conducted by specialists of the Saint Petersburg State University of Architecture and Civil Engineering under the Saint Petersburg target program "Preservation and Development of Konyushennaya and Northern Kolomna - New Holland Territories in the Historical Center of Saint Petersburg for 2013-2018".

During the inspection, the following issues were identified:

- significant wear of the buildings (more than $15 \%$ of the buildings have wear exceeding $40 \%$, and 45 buildings have wear of $20-40 \%$ ); 
- more than 30,000 communal apartments;

- no hot water supply in a significant number of apartment buildings;

- worn out facilities of the utility, municipal and transport infrastructure, public amenities;

- insufficient number of improved comfort areas.

Due to limited financial capabilities of Saint Petersburg, two territories were proposed to be allocated for implementation of the Program within the specific boundaries of the historical center: territory 1 located in the Tsentralny District of Saint Petersburg (Konyushennaya); territory 2 located in the Admiralteyskiy District of Saint Petersburg (Northern Kolomna - New Holland). The proposed zoning ensured an integrated approach to preservation and development of the Konyushennaya and Northern Kolomna - New Holland territories, as well as coordination of various types of works within their boundaries (Fig. 1, 2).

Boundaries of the Konyushennaya territory: from the crossing of the Dvortsovaya (Palace) Embankment and Lebyazhya (Swan) Canal to the Moyka River embankment, along the Moyka River embankment to the west to the Konyushennaya Square, along the Konyushennaya Square to the west to the crossing with the Griboyedov Canal, along the Griboyedov Canal to the south to the Nevsky Prospekt, along the Nevsky Prospekt to the west to the Moyka River embankment. Along the Moyka River embankment to the north to the Zimnyaya (Winter) Canal, along the Zimnyaya (Winter) Canal to the north to the Dvortsovaya (Palace) Embankment, along the Dvortsovaya (Palace) Embankment to the east to the crossing with the Lebyazhya (Swan) Canal. Boundaries of the Northern Kolomna - New Holland territory: from the crossing of the Novo-Admiralteyskiy Canal and Admiralteyskiy Canal embankments to the north along the Novo-Admiralteyskiy Canal embankment to the Angliyskaya (English) Embankment. Along the Angliyskaya (English) Embankment to the east to the Truda (Labor) Square. From the Truda (Labor) Square to the south along Truda Street to the crossing of Bolshaya Morskaya Street and Glinki Street. From Glinki Street to the west along the Moyka Embankment to the crossing with the Kryukov Canal embankment. Along the Kryukov Canal embankment to the south to Dekabristov Street. Along Dekabristov Street to the west to Minskiy Lane, along Minskiy Lane to the south along Soyuza Pechatnikov Street. Along Soyuza Pechatnikov Street to the west to Lermontovskiy Prospekt, then to the north to Dekabristov Street. Along Dekabristov Street to the west to the Pryazhka River embankment, then to the north along the Pryazhka River embankment to the Moyka River embankment. Along the Moyka River embankment to the east to the Novo-Admiralteyskiy Canal embankment.

These territories are located in the central part of the city in the area of the city's historical center. The historical center is built up with permanent low-rise houses $\left(18^{\text {th }}-19^{\text {th }}\right.$ centuries) with inclusions of multi-story buildings of the second half of the 19th century early 20th century. The buildings are characterized by high density, perimetral blocks, lack of industrial buildings, except for the Semyonov confectionery not included in the targeted program. 
Territory 1

KONYUSHENNAYA

CULTURAL HERITAGE SITES (CHS) AND IDENTIFIED SITES

Ф P.CHS of federal and regional importance

B - Identified sites

B. Non-listed identified sites
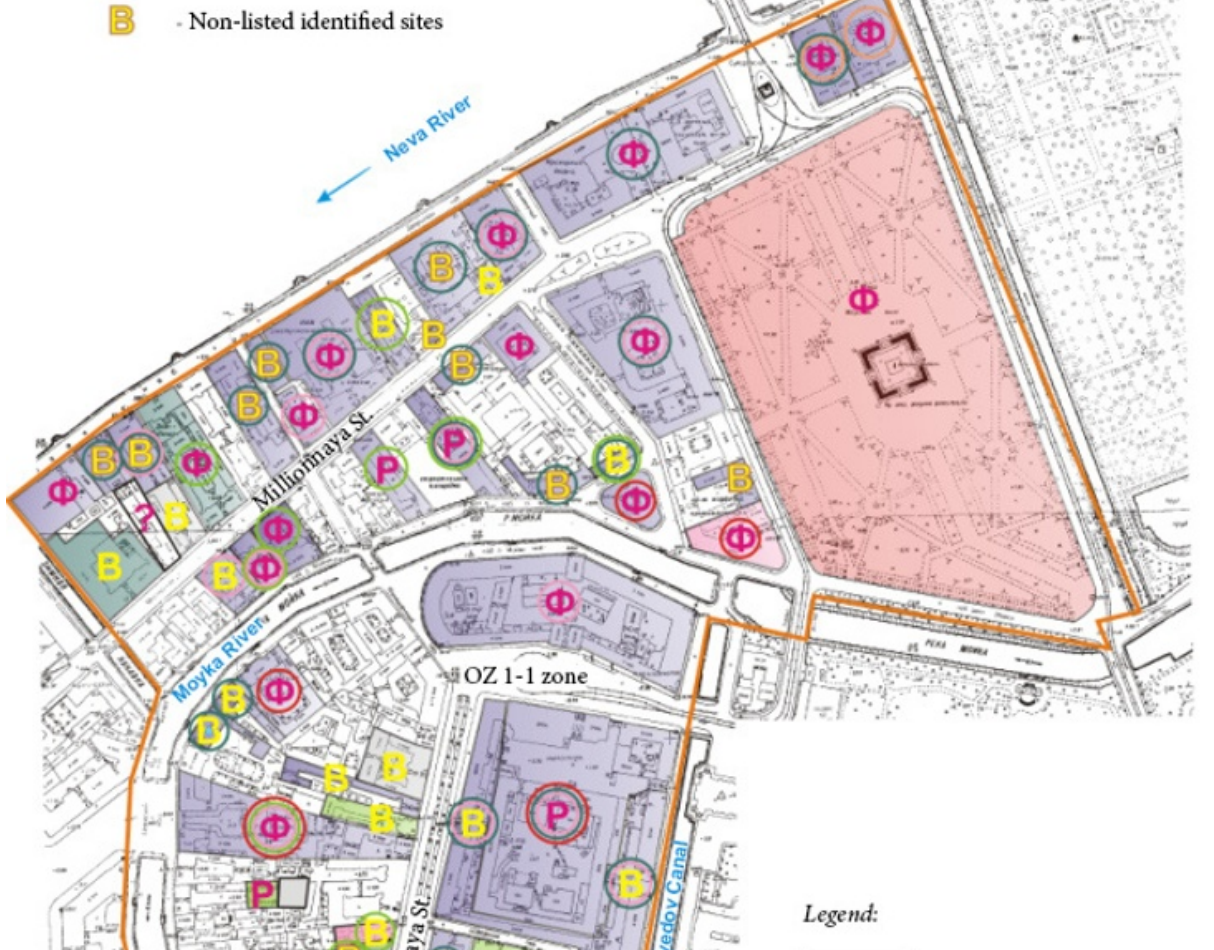

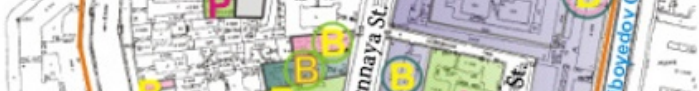
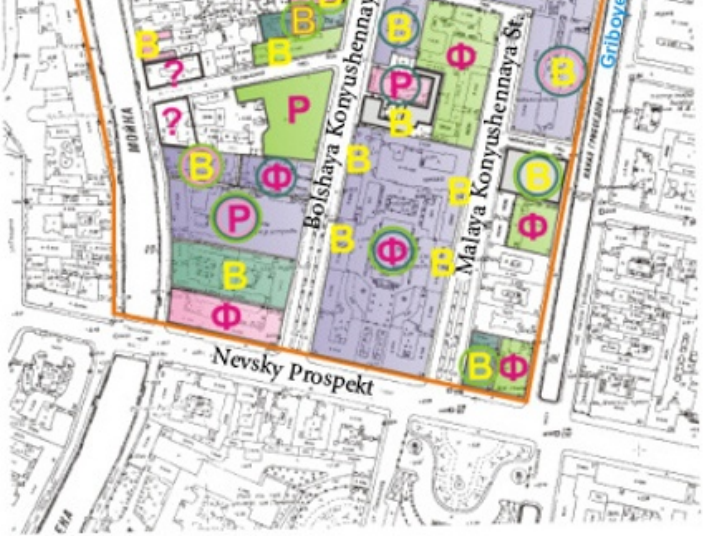

Legend:

\begin{tabular}{|c|l}
\hline highlight Ing & Construction period \\
\hline \hline drde & Reconstruction period \\
\hline \hline$?$ & $\begin{array}{l}\text { Construction period } \\
\text { is not specified }\end{array}$ \\
$\begin{array}{c}\text { Site is given in the diagram, } \\
\text { no data in guides or lists }\end{array}$ \\
\hline
\end{tabular}

Construction periods:

\begin{tabular}{|c|c|}
\hline & Late 18th century \\
\hline 10 & First half of the 19th century \\
\hline $\mathrm{O}$ & $\begin{array}{l}\text { Middle-second half } \\
\text { of the } 19 \text { th century }\end{array}$ \\
\hline $\mathrm{O}$ & Late 19th century - 1917 \\
\hline 0 & $\begin{array}{l}\text { Soviet period } \\
\text { (pre-war) }\end{array}$ \\
\hline
\end{tabular}

Fig. 1. Territory 1: Konyushennaya 
Territory 2

KOLOMNA

CULTURAL HERITAGE SITES (CHS) AND IDENTIFIED SITES

Ф P . CHS of federal and regional importance

- Identified sites

B - Non-listed identified sites

Construction periods:

\begin{tabular}{|l|l}
\hline & Late 18 th century \\
\hline & First half of the 19th century \\
& $\begin{array}{l}\text { Middle-second half } \\
\text { of the 19th century } \\
\text { Late } 19 \text { th century - } 1917 \\
\text { Soviet period } \\
\text { (pre-war) }\end{array}$ \\
\hline &
\end{tabular}

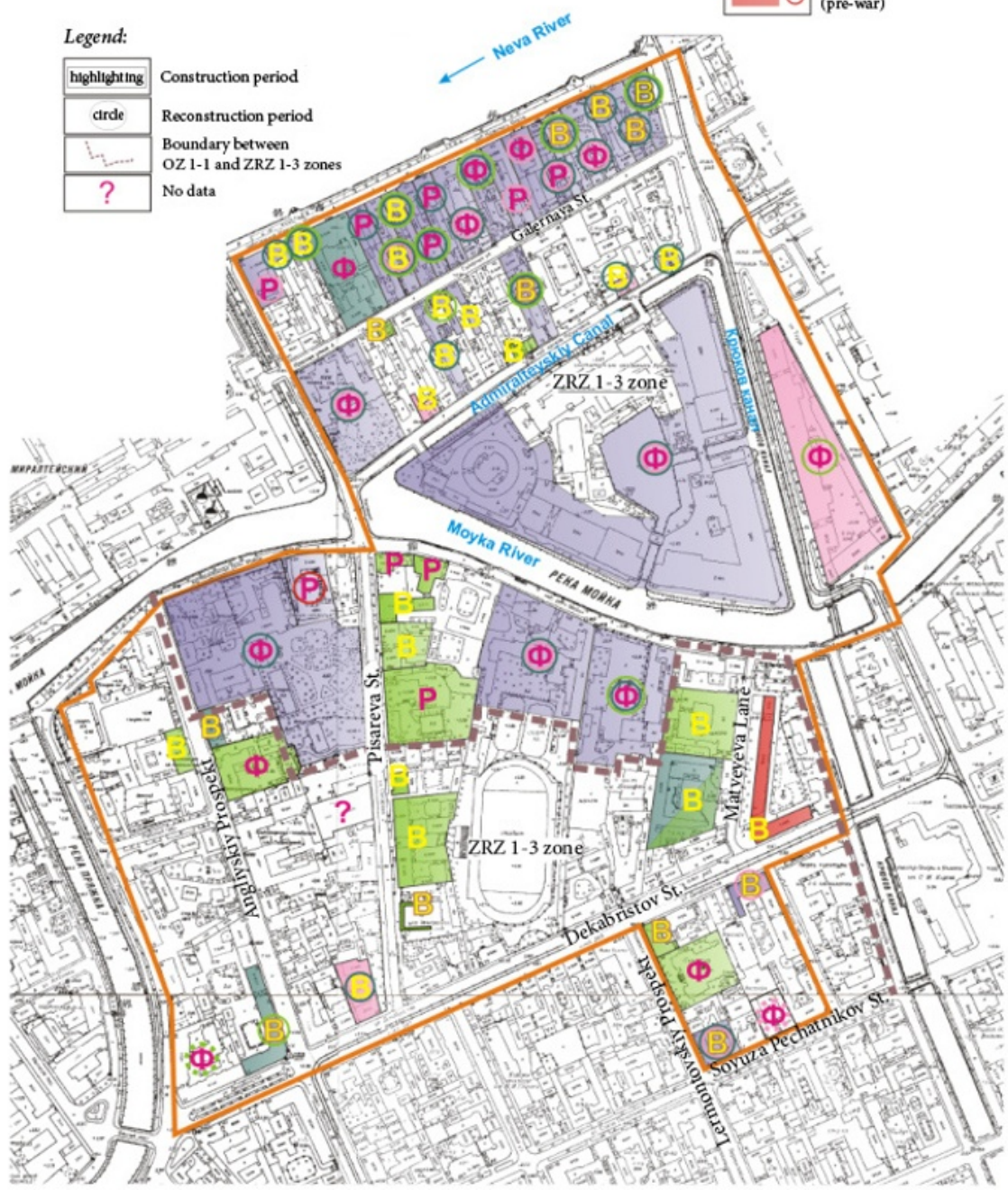

Fig. 2. Territory 2: Northern Kolomna - New Holland

The inspected buildings are made of brick and mainly have five floors, with longitudinal bearing walls (external walls and one internal wall, less commonly - with two internal walls forming a corridor) or with transverse bearing walls. Bricks made of clay were laid with mortar. Rigidity of the buildings is ensured by massive bonded longitudinal and transverse walls, including the walls of stairways. In some cases, rigidity of a building was improved with metal tie rods. 1-3 floors were added to many buildings during their operation. Most buildings have signs of uneven deformations. 
Intermediate and attic floors in the buildings that have not undergone renovation are usually made of timber beams with wooden filling, and in the buildings constructed later with metal beams with wooden filling; the basement ceiling is made with concrete on crushed brick or brick filling (in rare cases, intermediate floors have the same structure). The buildings constructed earlier mainly have arch brick basement (semi-basement) ceilings. The roofing is pitched, metal with wooden trussing and roof boarding. In places with excessive moistening (due to leaks or masonry wetting), timber elements rot, or are damaged by fungi, metal beams are corroded.

The buildings mainly have spread foundations of rubble stone. Short wooden piles under the foundations performed the function of earth compaction and did not serve as load-bearing structures (taking into account the peculiarities of engineering and geological conditions in the center of the city) $[23,24]$. The foundation footings frequently have grating beams. In the area of the varying first water-table aquifer, wooden elements may rot. The most part of some foundations is made of over-burned brick. Due to building settling and upheaval of the cultural layer, some part of the wall brickwork (about half a meter) could have gone below the daylight surface. In this case, due to the direct contact of the brickwork with soil, the brickwork can be excessively moisturized, which causes efflorescence and - in case of multiple cycles of freezing and thawing — brickwork destruction. In some cases, foundations in early buildings are made of boulders placed in a trench, sometimes with further liming. Due to mortar wash-out from the brickwork, individual stones may have moved due to man-made exposure. The foundation depth is usually 1.5-3 m, but in some cases, for example, in dumped areas near river embankments, it may exceed $4.5 \mathrm{~m}$ and vary under the same building. There is no water-proofing along the foundation edge, but rubble masonry (made of lime and eruptive rocks) has no ability for capillary suction of moisture and, thereby, plays a role of horizontal water-proofing.

Internal utilities have a lifetime of 20-30 years. The buildings of the historical center have not undergone any scheduled systematic repair; therefore, the utilities require replacement almost everywhere.

Considering further activities in modernization of the existing territory within these zones, the outcome of the program "Preservation and Development of Konyushennaya and Northern Kolomna - New Holland territories" shall be as follows:

- resettlement of 570 communal apartments;

- improvement of housing conditions of citizens registered as those in need of residential premises in Saint Petersburg;

- creation of two new areas of comfortable pedestrian traffic and one new pedestrian street;

- repair of green spaces located in the area of 13.29 ha of common public green spaces;

- reconstruction of the Sennaya Square with provision of transport hubs;

- renovation of 17 bridges and $1256.6 \mathrm{~m}$ of river embankments;

- completion of integrated reconstruction of the main water supply station;

- treatment of $100 \%$ waste water sludge in the central part of Saint Petersburg with respect to waste water re-channeling;

- construction of the Moskovskaya-Tovarnaya substation;

- reconstruction of $14 \mathrm{~km}$ of water supply networks, $27 \mathrm{~km}$ of sewage systems, reducing the number of sewer sumps by 137 units, $1.37 \mathrm{~km}$ of tunnel sewers, more than 9 $\mathrm{km}$ of gas pipelines of various diameter, more than $17 \mathrm{~km}$ of heat supply networks;

- reconstruction of more than $10 \mathrm{~km}$ of external lighting networks;

- installation of 10 tourist-informational booths in the center of Saint Petersburg;

- increasing of the number of tourists;

- development of two hotels; 
- development of a social and business multi-functional center on the New Holland island.

These measures allowed the Government of Saint Petersburg to develop a number of programs one of which being the Regional Program for Major Repair of Common Facilities in Apartment Buildings for 2014-2043.

Priorities in major repair of common facilities in apartment buildings included in the regional program of major repair were determined based on the following criteria:

1) wear of the apartment building;

2) date of previous (complete or partial) major repair of common facilities in the apartment building;

3) operational life of a structural element or type of utility equipment being a part of common facilities in the apartment building, in relation to the minimum operational life of structural elements and utility equipment of buildings as established by the applicable industry-specific construction regulations.

The need for major repair or reconstruction and works intended to preserve cultural heritage sites was determined based on building fitting (in terms of its technical condition) into one of the four categories specified by the methodology for technical inspection of buildings located in the Konyushennaya and Northern Kolomna - New Holland territories, proposed by specialists of the Saint Petersburg State University of Architecture and Civil Engineering and adopted by the Expert and Consulting Committee of the Council for Preservation and Development of territories in the Saint Petersburg Historical Center under the Government of Saint Petersburg (March 26, 2014):

Category 1 - no need for major repair, reconstruction or works to preserve cultural heritage sites (MR-P);

Category 2 - the need for MR-P is determined by the monitoring results;

Category 3 - scheduled MR-P is needed;

Category 4 - urgent MR-P is needed.

Such parameters as relative differential settlements, tilt, crack width, value of deflection of flexible members, destruction depth of structural elements, settlement speed, deficit in load-bearing capacity of a structural element, and compliance with the requirements for energy saving related to external enclosing structures (walls, attic ceilings, roofing) were taken as criteria to determine the building category in terms of the need for MR-P.

During the technical inspection of more than 130 residential buildings in the Konyushennaya and Northern Kolomna - New Holland territories, the following building categories were determined in terms of the need for major repair and reconstruction depending on physical wear of structural elements and buildings in general: $37 \%$ of buildings were classified as category 1 requiring no major repair, 20\% - as category 2 requiring planning of major repair, 33\% - as category 3 requiring planning of scheduled major repair and $10 \%$ - as category 4 requiring urgent major repair.

The analysis of the major repair program revealed a number of issues. In particular, they are related to proper selection of the type of major repair (selective or complete) as well as the work priority. Furthermore, in case of major repair of an apartment building, or reconstruction of historical cultural heritage sites, activities improving energy efficiency of buildings are almost always required, which are associated with significant costs that sometimes exceed the federal or city budget.

The results of checking thermal calculations of external walls, attic ceilings and roofing, made during the technical inspection of buildings in the historical center of Saint Petersburg show that in terms of energy saving, external brick walls without any additional thermal protection satisfy regulatory heat requirements for $30-45 \%$, and attic ceilings and roofing - for $25-40 \%$. 
Such non-compliance with the requirements of regulatory documents is related to Russian construction rules and regulations of new generation for thermal protection of buildings, developed and put into effect in 2010. They are intended for energy saving of buildings at any construction and operation stage. These rules and regulations are harmonized with similar foreign regulations of developed countries. They cover design of enclosures for new and reconstructed buildings and structures of various purpose, and are intended for thermal protection of residential, industrial and agricultural facilities.

Their application is compulsory in order to: protect life and health of people; ensure environmental protection and reduce carbon dioxide emissions. Using new regulations in the sector of residential construction allows reducing energy expenditures in their operation by $40 \%$ [25]. The reduction of energy costs will undoubtedly affect the economic efficiency indicators in the operation of modernized buildings, and in the future will affect the market value of housing. At the same time, it should be remembered that major repairs and energysaving measures require different costs and have different effects on reducing energy consumption. However, it is in the overhaul laid the main reserves of energy savings. The application of the described methodology will allow not only to determine the list of required costs for capital repairs, but also to assess the possibility of implementing the Smart City 2.0 strategy within the historical city.

\section{Conclusion}

It should be noted that major repair and reconstruction efficiency improvement shall be based on accurate data on the actual technical condition of the inspected facilities, that allow defining the necessary and sufficient list of works, their scope and cost. This is especially important when implementing the concepts of Smart City and Smart Home intended to become a basis for development of modern urban environment within the existing historical city. The described methodology developed by the authors serves a basis to find the most efficient solution for issues arising in Saint Petersburg, and fully meets all social, scientific, technical and economic conditions of modern urban development

\section{References}

1. I.A. Vasilenko Smart cities in XXIst century: the potential and risks of smart technologies in city rebranding (Moscow, 2018).

2. I.A. Gordin, Yu.O.Tolstykh, N.M. Lyulkina The analysis of experience of formation and implementation of regional programs of capital repairs in regions of the Russian Federation (2014) science-education.ru/ru/article/view?id=15586.

3. M.T. Makieva, N.I. Khosroeva Mezhdunarodny Nauchny Almanakh, 4, 162-170 (2016).

4. H. Chourabi, T. Nam, S. Walker Proceedings of the 45th Hawaii International Conference on System Sciences, 2289-2297 (2012).

5. V.S. Vagin, S.G. Sheina, K.V. Chubarova Naukovedenie (2015) naukovedenie.ru/PDF/116TVN315.pdf.

6. L. Lavrov, F. Perov Architecture and Engineering, 1, 4, 11-22 (2019).

7. P.G. Grabovy, A.E. Naumov, I.P. Avilova International Business Management, 10, 7, 1354-1364 (2016).

8. S. Sheina, L.L. Babenko Eastern European Scientific Journal, 5, 123-127 (2013).

9. S. Sheina, A. Fedorovskaya, K.Yudina IOP Conference Series: Materials Science and Engineering, 463, 2 (2018) doi.org/10.1088/1757-899X/463/3/032095. 
10. J. Gadecki II National Interdisciplinary Scientific Conference TechSpo'18: Power of Algorithms, 15-19 (2018).

11. L. Lavrov, E. Molotkova Architecture and Engineering, 40-52 (2019).

12. N. Komninos Intelligent cities: innovation, knowledge systems, and digital spaces (Abingdon: Routledge, 2002).

13. N. Odendaal Computers, Environment and Urban Systems, 6, 27, 585-607 (2003).

14. E. Moshninova, N. Novokhodskaia Architecture and Engineering, 22-28, 2018.

15. O.V. Averyanova Magazine of Civil Engineering, 23, 5, 53-59 (2011).

16. A.S. Gorshkov Magazine of Civil Engineering, 11, 1, 9-13 (2010).

17. A.S. Gorshkov, N.I. Vatin, P.P. Rymkevich, O.O. Kydrevich Magazine of Civil Engineering, 78, 2, 65-75 (2018).

18. L.L. Goshka Magazine of Civil Engineering, 11, 1, 14-22 (2010).

19. T.Datsuk, V. Pukhkal, U. Ivlev Advanced Materials Research, 1020, 643-648 (2014).

20. E. B. Smirnov, T.A. Datciuk, V. R. Taurit Water and ecology, 3, 82-98. (2017).

21. Energy statistics - an overview : Statistics Explained. (2019) ec.europa.eu/eurostat/statistics-explained/pdfscache/29046.pdf.

22. Primary energy consumption by fuel (2019) https://www.eea.europa.eu/data-andmaps/indicators/primary-energy-consumption-by-fuel-6/assessment-2.

23. S. V. Sementsov, E. A. Akhmedova, V. I. Volkov Water and Ecology, 4, 86-94 (2017).

24. R. Faltinsky, G. Tokunova SHS Web of Conferences (2018) https://doi.org/10.1051/shsconf/20184400033.

25. G.F. Tokunova Advanced Materials Research, 1020, 849-853 (2014). 